\title{
Risk factors for viral hepatitis A infection in Gampaha District, Sri Lanka: an unmatched case control study
}

\author{
Nalin Ariyarathna ${ }^{1}$ and Chrishantha Abeysena ${ }^{2^{*}}$
}

\begin{abstract}
Background: Hepatitis A virus (HAV) is one of the commonest food and water borne infectious diseases. The objective of the study was to determine the risk factors of HAV infection in the Gampha District in Sri Lanka.

Methods: This was an unmatched case control study conducted between January 2015 and November 2016 comprising of 504 participants with a case control ratio of 1:1. The study population included individuals of age 1 year and above who were permanent residents of the district. Cases included participants admitted to four secondary care state hospitals with an acute HAV diagnosed by detecting serum anti-HAV IgM antibodies. Controls were randomly selected individuals from the community with serum negative for Anti-HAV IgM and lgG. An interviewer administered questionnaire was used for the data collection and multiple logistic regression was applied to determine the independent risk factors. The results are expressed as adjusted odds ratios (AOR) and 95\% confidence intervals (Cl).

Results: Risk factors for HAV infection were poor knowledge regarding hepatitis (AOR;3.98, 95\% Cl=1.97-8.05), unhygienic sanitary practices $(\mathrm{OR}=2.73 ; 95 \% \mathrm{Cl}=1.42-5.23)$, unhygienic practices related to drinking water $(\mathrm{OR}=2.67 ; 95 \% \mathrm{Cl}=1.37-5.21)$, residing in urban areas $(\mathrm{OR}=5.94 ; 95 \% \mathrm{Cl}=2.98-11.86)$ and lower family income $(\mathrm{OR}=2.83 ; 95 \% \mathrm{Cl}=1.30-6.13)$.

Conclusions: The independent modifiable risk factors for HAV infection were poor knowledge regarding hepatitis, unhygienic sanitary practices, and unhygienic practices related to drinking water. Community awareness must be raised on hygienic practices and safe water drinking practices. Inequities of social determinates of health must be addressed.
\end{abstract}

Keywords: Water, Hepatitis, Hygiene, Risk, Sanitation

\section{Background}

Acute viral hepatitis is a systemic illness that predominantly affects liver causing clinical symptoms that include jaundice, dark urine and tender hepatomegaly with fever. Hepatitis A, B, C, D, and E are responsible for almost all the cases of viral hepatitis. The sero-prevalence of

\footnotetext{
* Correspondence: chrishantha-abeysena@kln.ac.lk;

chrishanthaabeysena@yahoo.com

${ }^{2}$ Senior Professor in Community Medicine, Department of Public Health,

Faculty of Medicine, University of Kelaniya, Kelaniya, Sri Lanka

Full list of author information is available at the end of the article
}

Hepatitis A virus (HAV) was $80.7 \%$ in Sri Lanka (14), 63.8\% in Korea (12) and 41.1\% in Australia (13). Generally, HAV infections are self-limiting without symptoms or with non-specific symptoms, and a low mortality. More severe cases of HVA are admitted for inward care and given supportive treatment combined with close monitoring. Nevertheless, for those who experience symptomatic illness, treatment costs, loss of productivity and human suffering can be significant $[1-3]$.

C C The Author(s). 2020 Open Access This article is licensed under a Creative Commons Attribution 4.0 International License, which permits use, sharing, adaptation, distribution and reproduction in any medium or format, as long as you give appropriate credit to the original author(s) and the source, provide a link to the Creative Commons licence, and indicate if changes were made. The images or other third party material in this article are included in the article's Creative Commons licence, unless indicated otherwise in a credit line to the material. If material is not included in the article's Creative Commons licence and your intended use is not permitted by statutory regulation or exceeds the permitted use, you will need to obtain permission directly from the copyright holder. To view a copy of this licence, visit http://creativecommons.org/licenses/by/4.0/ The Creative Commons Public Domain Dedication waiver (http://creativecommons.org/publicdomain/zero/1.0/) applies to the data made available in this article, unless otherwise stated in a credit line to the data. 
According to a study, young children are mostly asymptomatic leading to a higher spread of the disease [4] and several studies reported that the risk of hepatitis A increases with age [5-7]. Other associated factors were living on a low family income $[8,9]$ and lower educational level $[9,10]$. The transmission of Hepatitis A occurs most commonly through the faeco-oral route and consequently, consumption of contaminated food and water plays an important role in the spreading of HAV. Consumption of contaminated food was identified as the commonest cause for both sporadic cases and outbreaks of HAV $[4,11]$. One study carried out in 2004 identified not having access to tap water as a risk factor for hepatitis A infection [12]. A number of studies showed that poor sanitation was a risk factor for HAV infection [12, 13]. In addition, it can be expected that the peoples' knowledge regarding HAV and the spread of the disease can be thought to be associated with the prevalence of HAV infection.

Despite the fact that the risk factors for HAV are well recognized globally, to the best of the author's knowledge, no studies have been carried out to identify risk factors for HAV in Sri Lanka. The district of Gampaha is one of the most populous districts in Sri Lanka and it was felt important to assess the risk factors for HAV in the area. Determining the risk factor profile of viral hepatitis may well avert the occurrence and spread of disease by the introduction of rational preventive strategies. Since studies to identify HAV risk factors were not conducted in Sri Lanka prior to this, this study would explore the much needed data for HAV disease prevention. Hence, studying the risk factors comprehensively helps to formulate well focused cost effective preventive strategies to prevent HAV infections. Results of the proposed study would provide knowledge for proper planning for the prevention of the disease by risk factor identification. The objective of the study was to determine the risk factors for viral hepatitis $\mathrm{A}$ of a district in Sri Lanka.

\section{Methods}

An unmatched case control study was done recruiting hospital based cases and community based controls from the district of Gampaha between January 2015 and November 2016. The study population included individuals of age 1 year and above who were permanent residents of the District. A case was defined as a patient who was serologically confirmed as having HAV infection by detecting serum anti-HAV IgM antibodies by ELISA testing. A control was an individual who was serum negative for Anti-HAV IgM and IgG. Patients with severe psychiatric illnesses were excluded since the reliability of data was a concern. The cases were selected from four secondary care state hospitals and the controls from the community. The cases were selected consecutively during the study period. The Controls were individuals who were permanent residents in the district of Gampaha at the time of data collection. The controls were selected using a multi-stage stratified cluster sampling technique. The selection of the controls has been described elsewhere [14].

The sample size was calculated considering the exposure among the controls as 0.55 , the odds ratio as 1.75 [15], desired probability of type I error as 0.05 and the power as 0.80 . Therefore, the minimum of 221 samples of cases and controls were needed. Considering the nonresponse rate of $15 \%$, the required sample size was 260 for a group.

Data were collected through an intervieweradministered questionnaire (IAQ). It covered sociodemographic characteristics, knowledge of viral hepatitis, past clinical information of viral hepatitis, and risk factors of HAV. The information on history of viral hepatitis and clinical manifestations were confirmed only if documentary evidence were available.

The probable risk factors for viral HAV were searched on literature and they were found to be poor knowledge regarding viral hepatitis, unhygienic practices related to drinking water, unhygienic practices related food intake, unhygienic practices related sanitation, contact history of viral hepatitis, history of travel to endemic area, history of previous vaccination, and overcrowding in the household. The face and content validity of the questionnaire were assessed by experts and the relevant items under each domain were listed. These draft tools were sent to five public health experts for their opinion and they were asked to allocate a score out of 10 , taking into consideration the relevance of each variable to be retained in the tool. The score given for each item by the experts were added and the quartile analysis was done. The variables in the upper three quartiles were retained in the tool. The retained item variables were worded and a scoring system was developed for each probable risk factor. The re-drafted tools were recirculated among the five experts to seek their feedback on the wording and the scoring and based on their feedback, the final tool was developed (Additional file 1). It was prepared using simple language, avoiding technical terms as much as possible to ensure accurate and reliable responses from the participants. The questionnaire was then pre-tested to ensure its acceptability and understandability. Where required, corrections and improvements were made following the pre-testing process.

In the questionnaire, questions/statements regarding knowledge on viral hepatitis included the nature of the diseases, possible modes of transmission, possible risk factors for HAV, commonly affecting organs, common 
clinical features, and vaccination against HAV. Total score allocated for the entire section was 150 and the cutoff for poor knowledge was decided as the first quartile of the total score. In the case of children under 12 years of age parents' or the guardians' knowledge was assessed. The exposure to hygienic drinking water was assessed by 10 items on quality, accessibility and usage of water sources, safety of containers and purity and the total score was 45. 'Unhygienic practices related to drinking water' was defined according to an individual's aggregated score within the first quartile of the total score. The exposure to hygienic sanitation was assessed by 13 items on quality, availability of water, availability of soap, hand washing and related practices, waste disposal, and waste segregation, and the total allocated marks were 45 . 'Unhygienic sanitary practices' was defined according to an individual's aggregated score within the first quartile of the total score. The exposure to hygienic food intake was assessed by 11 items on quality, safe storage, cooking practices, selection of food and maintaining temperature and the total score was 50 . 'Unhygienic food practices' was defined according to an individual's aggregated score within the first quartile of the total score. A score was allocated to each item of the above probable risk factors assessed and the total score depended on the type of items, type of response, and the number of possible responses. The cutoff for each probable risk factor was decided with the experts' views. Contact history of patient with icterus during previous 1 month, travel to high risk countries during previous 1 month, stay out of district of the Gampaha district for more than $24 \mathrm{~h}$ during the past 1 month were assessed. Lack of vaccination against HAV was assessed by asking of receiving two doses of inactivated or activated vaccine.

The IAQ was pre-tested by administering it to 10 clinically suspected cases with HAV in another Hospital which was not included as a setting in the study. Two trained pre-intern medical graduates were selected as interviewers for the study. For the case group, data were collected from the eligible patients in the hospital. For the control group, the selected households were visited for data collection. Interviewers were trained on the administration of the questionnaire to ensure uniform and accurate process of data collection. They were instructed to read out the questionnaire in its exact form in order to ensure minimal effect of the interviewer on the outcome. The interviewers were blinded. In this way interviewer bias has been avoided during the administration of the questionnaire to a certain extent.

Blood samples were collected by nursing officers according to strict aseptic procedures within the first 2 days of admission to the relevant hospital. Once collected, correctly labelled samples were kept in the refrigerator until they were transported to the laboratory facility. Serum samples were stored in a specific storage in the laboratory facility under minus 20 Centigrade temperature until the testing was performed. Serological tests were performed in the Department of Microbiology, Faculty of Medicine, University of Colombo under direct supervision of a senior Microbiologist. Anti-HAV IgM test was done by AccuDiag ELISA kits for suspected HAV cases while both Anti-HAV IgM and IgG test were done for controls. These particular tests (Anti-HAV IgM and Anti-HAV IgG) had 99\% specificity and 100\% sensitivity.

Data analysis was performed by Statistical Package for Social Sciences version 16. Probable risk factors were determined by bivariate analysis and multiple logistic regression was performed in order to identify independent risk factors. The variables with probability value up to 0.20 in the bivariate analysis were included into the multivariate model [15]. The adjusted odds ratios (AOR), and 95\% confidence intervals (CI) were calculated.

The Ethics Review Committee of the Medical Research Institute of Sri Lanka granted ethical clearance for the study and written informed consent was obtained. All procedures were complying with the ethical standards of the relevant national and institutional guidelines including the Helsinki Declaration of 1975, as revised in 2008 and the International Ethical Guidelines for Biomedical Research Involving Human Subjects in 2002.

\section{Results}

Two hundred and fifty two individuals were recruited as cases and another 252 individuals as controls. Majority of the controls belonged to the age group of 11 to 20 ( $n=106,42 \%)$ while majority of the cases belonged to the age group of 21 to $30(n=69,27.4 \%)$. Fifty six per cent $(n=141)$ among the cases were males while the proportion of males among the controls were 39.3\% $(n=99)$. In both the groups, majority of the participants belonged to the Sinhalese and Buddhist religious group. Married and unmarried individuals were more or less equal among the cases while majority $(n=192,76.19 \%)$ of the individuals were unmarried among the controls. There were 160 (63.3\%) and 115 (45.6\%) individuals who were educated up to Grade 10 among the cases and controls respectively.

There were statistically significant associations between the presence of HAV infection and being above 13 years of age, being a male, being Buddhist, being Sinhalese, being married, having a low family income, being previously or currently employed, living in an urban area, having a higher number of members in the family, sharing toilets with a higher number of members in the family, foreign trips and out visits from the district of Gampaha (Table 1). 
A statistically significant association was observed between the poor knowledge regarding viral hepatitis, unhygienic practices related to drinking water, unhygienic sanitary practices, and unhygienic food practices with the presence of HAV infection by bivariate analysis (Table 2).
Living in an urban area, (AOR-5.9, 95\% CI $=2.98$ 11.86), low income of the family (AOR $2.82,95 \% \mathrm{CI}=$ 1.30-6.13), poor knowledge regarding viral hepatitis (AOR 3.89, 95\%CI $=1.97-8.05$ ), unhygienic sanitary practices (AOR 2.73, 95\% CI $=1.42-5.23$ ), and unhygienic

Table 1 Association with HAV infection and selected socio demographic characteristics of the participants

\begin{tabular}{|c|c|c|c|c|}
\hline $\begin{array}{l}\text { Socio demographic } \\
\text { characteristics }\end{array}$ & $\begin{array}{l}\text { Cases }(\boldsymbol{N}=252) \\
\mathrm{n}(\%)\end{array}$ & $\begin{array}{l}\text { Controls }(N=252) \\
\mathrm{n}(\%)\end{array}$ & OR $(95 \% \mathrm{Cl})$ & $\bar{p}$ value \\
\hline Age & & & $2.02(1.3-3.1)$ & \\
\hline$>13$ years & $213(84.5)$ & $184(73.0)$ & & \\
\hline$\leq 13$ years & $39(15.5)$ & $68(27.0)$ & & 0.002 \\
\hline \multicolumn{5}{|l|}{ Sex } \\
\hline Male & $141(56.0)$ & 99 (39.3) & $1.9(1.38-2.8)$ & \\
\hline Female & $111(44.0)$ & $153(60.7)$ & & 0.001 \\
\hline \multicolumn{5}{|l|}{ Marital Status } \\
\hline Unmarried & $132(52.4)$ & $192(76.2)$ & $0.36(0.24-0.53)$ & \\
\hline Married & $115(45.6)$ & $60(23.8)$ & & $<0.001$ \\
\hline \multicolumn{5}{|l|}{ Religion } \\
\hline Buddhism & $250(99.2)$ & $219(86.9)$ & $18.8(4.46-79.4)$ & \\
\hline Catholic & $2(0.8)$ & $33(13.1)$ & & $<0.001$ \\
\hline \multicolumn{5}{|l|}{ Ethnicity } \\
\hline Sinhala & $252(100.0)$ & $246(97.6)$ & $2.02(1.85-2.21)$ & \\
\hline Tamil & $0(0.00)$ & $6(2.4)$ & & 0.01 \\
\hline \multicolumn{5}{|l|}{ Family income } \\
\hline$<20,000$ LKR & $169(85.8)$ & $184(73.0)$ & $2.23(1.37-3.63)$ & \\
\hline$\geq 20,000$ LKR & $28(14.2)$ & $68(27.0)$ & & 0.001 \\
\hline \multicolumn{5}{|c|}{ Highest level of education } \\
\hline Up to $\mathrm{O} / \mathrm{L}$ & $182(76.5)$ & $188(74.6)$ & $1.10(0.73-1.67)$ & \\
\hline Above $\mathrm{O} / \mathrm{L}$ & $56(23.5)$ & $64(25.4)$ & & 0.63 \\
\hline \multicolumn{5}{|l|}{ Occupation } \\
\hline Other & $154(61.1)$ & $221(87.7)$ & $0.22(0.14-0.36)$ & \\
\hline Paid worker/Retired & $98(38.9)$ & $31(12.3)$ & & 0.001 \\
\hline Urban & $101(40.1)$ & $36(14.3)$ & $4.01(2.60-6.19)$ & \\
\hline Rural & $151(59.9)$ & $216(85.7)$ & & $<0.001$ \\
\hline \multicolumn{5}{|c|}{ Number of family members sharing the household } \\
\hline$\geq 5$ members & $56(22.2)$ & $104(41.3)$ & $0.41(0.28-0.60)$ & \\
\hline$<5$ members & $196(77.8)$ & $148(58.7)$ & & $<0.001$ \\
\hline \multicolumn{5}{|c|}{ Family members sharing the toilet } \\
\hline$\geq 5$ members & $137(54.4)$ & $179(71.0)$ & $0.49(0.34-0.70)$ & \\
\hline$<5$ members & $115(45.6)$ & $73(29.0)$ & & $<0.001$ \\
\hline \multicolumn{5}{|c|}{ Out visits from Gampaha } \\
\hline Yes & $34(13.5)$ & $152(60.3)$ & $0.10(0.06-0.16)$ & \\
\hline No & $218(86.5)$ & $100(39.7)$ & & $<0.001$ \\
\hline \multicolumn{5}{|l|}{ Travelled abroad } \\
\hline Yes & $0(0.0)$ & $42(16.7)$ & $0.45(0.41-0.50)$ & \\
\hline No & $252(100)$ & $210(83.3)$ & & $<0.001$ \\
\hline
\end{tabular}

OR odds ratio, $\mathrm{Cl}$ confidence interval 
Table 2 Association of HAV infection with knowledge about viral hepatitis and practices

\begin{tabular}{|c|c|c|c|c|}
\hline & $\begin{array}{l}\text { Cases }(\boldsymbol{N}=252) \\
\mathrm{n}(\%)\end{array}$ & $\begin{array}{l}\text { Controls }(\boldsymbol{N}=252) \\
\text { n }(\%)\end{array}$ & OR $(95 \% \mathrm{Cl})$ & $\boldsymbol{p}$ value \\
\hline \multicolumn{5}{|c|}{ Knowledge regarding viral hepatitis } \\
\hline Poor knowledge & $92(36.5)$ & $35(13.9)$ & $3.56(2.30-5.53)$ & \\
\hline Good knowledge & $160(63.5)$ & $217(86.1)$ & & $<0.001$ \\
\hline \multicolumn{5}{|c|}{ Practices related to drinking water } \\
\hline Unhygienic & $88(34.9)$ & $54(21.4)$ & $1.97(1.32-2.93)$ & \\
\hline Hygienic & $164(65.1)$ & $198(78.6)$ & & \\
\hline \multicolumn{5}{|l|}{ Sanitary practices } \\
\hline Unhygienic & $97(38.5)$ & $53(21.0)$ & $2.35(1.58-3.49)$ & \\
\hline Hygienic & $155(61.5)$ & $199(79.0)$ & & $<0.001$ \\
\hline \multicolumn{5}{|l|}{ Food practices } \\
\hline Unhygienic & $110(43.7)$ & $40(15.9)$ & $4.10(2.70-6.25)$ & \\
\hline Hygienic & $142(56.3)$ & $212(84.1)$ & & $<0.001$ \\
\hline \multicolumn{5}{|c|}{ History of Hepatitis vaccination } \\
\hline Not vaccinated & $41(16.3)$ & $41(16.3)$ & $1.0(0.62-1.60)$ & \\
\hline Vaccinated & $211(83.7)$ & $211(8$ 3.7) & & 1.0 \\
\hline
\end{tabular}

practices related to drinking water $(\mathrm{AOR} 2.67,95 \% \mathrm{CI}=$ 1.37-5.21) were found as independent risk factors for HAV infection (Table 3). Being unmarried, being unemployed, out visits from the district of Gampaha, more than five family members living in a household and a higher number of members sharing a toilet in the household were inversely associated with HAV infection (Table 3).

\section{Discussion}

The study found that independent risk factors of HAV infection were poor knowledge regarding viral hepatitis, unhygienic practices related to drinking water, unhygienic sanitary practices, being in an urban area, and low income of the family.
One of the main preventive measures of viral hepatitis is avoidance of transmission for which knowledge regarding modes of transmission of the disease is vital. Assessment of knowledge regarding viral hepatitis is not commonly found in literature. We found that poor knowledge regarding viral hepatitis was an independent risk factor with the occurrence of HAV infection.

The present study depicted that the practices related to unhygienic drinking water were independent risk factors. Similar findings were observed a study conducted in Italy which had found that the surface water as a potential source for the HAV infection [16]. Three studies reported that usage of water from the public system was identified as a risk factor in Brazil [17], in France [18], and in Korea [19]. The common feature of all of these studies was that only one or two aspects

Table 3 Risk factors for HAV infection

\begin{tabular}{|c|c|c|c|c|c|}
\hline Variable & Beta coefficient & $\mathrm{AOR}$ & $95 \%$ & & $\boldsymbol{p}$ value \\
\hline Urban population & 1.78 & 5.94 & 2.98 & 11.86 & $<0.001$ \\
\hline Unmarried individuals & -1.35 & 0.26 & 0.14 & 0.46 & $<0.001$ \\
\hline Unemployed & -2.13 & 0.12 & 0.06 & 0.23 & $<0.001$ \\
\hline Income $<20,000$ LKR & 1.04 & 2.82 & 1.30 & 6.13 & 0.009 \\
\hline Poor knowledge regarding viral hepatitis & 1.38 & 3.98 & 1.97 & 8.05 & $<0.001$ \\
\hline Unhygienic practices related to drinking water & 0.98 & 2.67 & 1.37 & 5.21 & 0.004 \\
\hline Unhygienic sanitary practices & 1.00 & 2.73 & 1.42 & 5.23 & 0.003 \\
\hline Out visits from district of Gampaha & -2.19 & 0.11 & 0.06 & 0.21 & $<0.001$ \\
\hline$\geq 5$ family members living in a household & -1.01 & 0.36 & 0.19 & 0.75 & 0.006 \\
\hline$\geq 5$ family members using the toilet & -0.66 & 0.52 & 0.27 & 1.00 & 0.05 \\
\hline
\end{tabular}

$A O R$ adjusted odds ratio, $\mathrm{Cl}$ confidence interval 
were measured rather than focusing on the full spectrum of the risk profile under the practices related to unhygienic drinking water. In the current study, the risk of unhygienic drinking water was assessed as a composite variable including all aspects in relation to such practices.

Individuals who conformed to poor sanitary practices were at 2.72 times a risk than the individuals who follow proper sanity practices, according to the present study. One study conducted in Jordan reported that presence of public sewage system in the resident area was a protective factor for HAV infection [20]. In contrast availability of different types of toilets was not associated with HAV infection [20]. Another study conducted in Chile reported that neither the presence of a public sewage system nor the availability of a toilet were associated with HAV infection [21]. Availability of water and soap for toilet practices, hand washing and related practices, proper waste disposal and segregation were selected for the assessment of hygienic sanitation in the current study. Relevant questions were made in order to get the maximum information under the hygienic sanitation. Therefore, overall individual assessment regarding hygienic sanitation was possible in the current study rather than assessment of individual items. Further, this method was useful to perform unbiased assessment of individuals since overall situation regarding sanitation was evaluated.

People who live in urban sector had six times higher risk of HAV than people who live in rural sector. It is important to understand the reasons behind the risk of being in the urban sector in order to plan preventive strategies. Urban sectors are controlled by Urban Councils and Municipal Councils and facilities like pipeborne water, waste management, and many other facilities for the improvement of living standard are provided. However, this risk may be due to unplanned urbanization and poor living conditions in some areas due to high population density where waste management is observed to be not up to the standard [22]. Rural population may be protected due to their safe practices. In contrast, living in a rural area was identified as a risk factor for HAV in three studies [23-25].

Low income was independently associated with the occurrence of HAV infection. Low income level links with socioeconomic status of individuals or family [21, 26]. Hence the occurrence of HAV infection would be associated with low level of socioeconomic status and it is important to understand its implications. According to our findings, the variable such as education, number of family members sharing the household or toilet were significantly associated with hepatitis A infection. However, those variables became non-significant in the multivariate regression model. Further two studies showed that high socioeconomic states had low risk of HAV infection [21, 25].

There were a few limitations in the present study. Data collection was only dependent on the information given by the participants. The authors attempted to clarify any doubt in data collection by adopting several measures for improving quality of data. Further comprehensive socioeconomic status assessment has not been done. And as for the strengths of our study, we recruited a representative sample to minimize selection bias. Further, we used standardized questionnaire and trained interviewers to collect data. Standard techniques were used for drawing blood, storage and laboratory analysis. All of these methods minimized information bias.

\section{Conclusions}

Independent risk factors were living in an urban area, low income, poor knowledge regarding viral hepatitis, unhygienic practices related to drinking water and unhygienic sanitary practices. Apart from the poor knowledge regarding viral hepatitis being a risk factor, we confirmed the findings reported by other authors. Measures should be taken in order to increase knowledge on HAV among general public, work settings, schools and preventive/curative health care institutions. Practices related to safe water intake, personal hygiene, and proper sanitation should be improved through behavior-oriented programmes.

\section{Supplementary information}

Supplementary information accompanies this paper at https://doi.org/10 1186/s12889-020-08490-2.

Additional file 1. Risk factors for viral hepatitis A Infection

Questionnaire.

Abbreviations

AOR: adjusted odds ratios; Cl: confidence intervals; HAV: Hepatitis A virus; IAQ: Interviewer administered questionnaire

\section{Acknowledgements}

We are grateful to the study participants, the data collectors and the Postgraduate Institute of Medicine, University of Colombo.

\section{Authors' contributions}

NA participated in the design of the study, coordinated data collection, performed the statistical analysis and helped to draft the manuscript. CA participated in the design of the study, performed the statistical analysis, interpreted the data and drafted the first version of the manuscript. Both authors read and approved the final manuscript.

\section{Funding}

We hereby declare that the cost for serological tests (Research No: 65/2013) was funded by Medical Research Institute of the Ministry of Health, Sri Lanka. There wasn't any influence from the aforementioned institute during the process of conducting or report writing of this research.

Availability of data and materials

The datasets used and/or analysed during the current study are available from the corresponding author on reasonable request. 


\section{Ethics approval and consent to participate}

The Ethics Review Committee of the Medical Research Institute of Sri Lanka granted ethical clearance. Written informed consent was obtained from each of the selected participants prior to data collection. In case of a child (age < 18 years), written informed consent was obtained from the parents or from the guardian. Confidentiality was maintained while handing over individual serological reports

\section{Consent for publication}

Not applicable.

\section{Competing interests}

"The authors declare that they have no competing interests" in this section.

\section{Author details}

${ }^{1}$ Senior Registrar in Community Medicine, Ministry of Health, Sri Lanka. ${ }^{2}$ Senior Professor in Community Medicine, Department of Public Health, Faculty of Medicine, University of Kelaniya, Kelaniya, Sri Lanka.

Received: 19 September 2019 Accepted: 9 March 2020

Published online: 18 March 2020

\section{References}

1. Lucioni C, Cipriani V, Mazzi S, Panunzio M. Cost of an outbreak of hepatitis a in Puglia, Italy. Pharmacoeconomics. 1998;13(2):257-66. https://doi.org/10. 2165/ 00019053-199813020-00008.

2. Park HS, Choi BY, Kwon YD. Rapid increase in the national treatment costs for hepatitis a infections in Korea. Tohoku J Exp Med. 2012;226(1):85-93. https://doi.org/10.1620/tjem.226.85.

3. Zahdi M, Maluf IJ, Maluf E. Hepatitis A: The costs and benefits of the disease prevention by vaccine. Kindle ed. Parana, Brazil. Braz J Infect Dis. 2009;13(4):257-61.

4. Mandel G, Bennett J, Paphael DE. Principles and practice of Infectious disease. 7th ed: Elsevier; 2009. p. 2367-87. ISBN: 978-0-4430-6839-3 Volume 1: Part no. 9996058433.

5. Mall ML, Rai RR, Philip M, Naik G, Parekh P, Bhawnani SC, et al. Seroepidemiology of hepatitis a infection in India: changing pattern. Indian J Gastroenterol. 2001;20(4):132-5.

6. World Health Organization. In: Kindle, editor. The global prevalence of Hepatitis A viral infection and susceptibility, a systematic review. Geneva: World Health Organization; 2010.

7. Vitral $C L$, Silva-Nunes M, Pinto MA. Hepatitis a and E seroprevalence and associated risk factors: a community-based cross-sectional survey in rural Amazonia. BMC Infect Dis. 2014;14:458. https://doi.org/10.1186/ 1471-2334-14-458.

8. Markus JR, Cruz CR, Maluf EMCP, Tahan TT, Hoffmann MM. Seroprevalence of hepatitis a in children and adolescents. J Pediatr. 2011;87:5 https://doi. org/10.1590/S0021-75572011000500009.

9. Ximenes RAA, Martelli CMT, Merchán-Hamann E, Montarroyos UR, Braga MC, et al. Multilevel analysis of hepatitis a infection in children and adolescents: a household survey in the northeast and central-west regions of Brazil. Int J Epidemiol. 2008;37(4):852-61. https://doi.org/10.1093/ije/dyn114.

10. Merat S, Rezvan H, Nouraie M, Abolghasemi $H$, Jamali $R$, et al. Seroprevalence and risk factors of hepatitis A virus infection in Iran: a population based study. Arch Iran Med. 2010;13(2):99-104.

11. Yan Y. Risk factor for acute viral hepatitis: a case-control study. Zhonghua Liu Xing Bing Xue Za Zhi. 1992;13(1):5-8.

12. Jacobsen KAK, Koopman JS. The effects of socioeconomic development on worldwide hepatitis a virus sero-prevalence patterns. Int J Epidemiol. 2005; 34(3):600-9. https://doi.org/10.1093/ije/dyi062.

13. Schiff E, Maddrey W, Sorrell ME. Schiff's disease of the liver. Vol. 8th. New York: Lippincott; Wiley-Blackwell; 2011. https://doi.org/10.1002/ 9781119950509.

14. Ariyarathna N, Abeysena C. Sero-prevalence of viral hepatitis a in a district of Sri Lanka: a community based cross-sectional study. BMC Infect Dis. 2019; 19:443 https://doi.org/10.1186/s12879-019-4043-y.

15. Hosmer DW, Lemeshow S. Applied logistic regression. New York: Wiley; 1989.

16. laconelli M, Purpari G, Della Libera S, Petricca S, Guercio A, Ciccaglione AR, et al. Hepatitis a and $E$ viruses in wastewaters, in river waters, and in bivalve
Molluscs in Italy. Food Environ Virol. 2015;7(4):316-24. https://doi.org/10. 1007/s12560-015-9207-3.

17. Mantovani SAS, Delfino BM, Martins AC, Oliart-Guzmán H, Pereira TM, Branco FLCC, et al. Socioeconomic inequities and hepatitis a virus infection in Western Brazilian Amazonian children: spatial distribution and associated factors. BMC Infect Dis. 2015;15:428.

18. Lagarde E, Joussemet M, Lataillade J, Fabre G. Risk factors for hepatitis a infection in France: drinking tap water may be of importance. Eur J Epidemiol. 1995;11(2):145-8. https://doi.org/10.1007/bf01719479.

19. Yoon YK, Chun BC, Lee HK, Seo YS, Shin JH, Hong YS, et al. Epidemiological and genetic analysis of a sustained community-wide outbreak of hepatitis a in the Republic of Korea, 2008: a hospital-based case-control study. J Clin Virol. 2009:46(2):184-8. https://doi.org/10.1016/j.jcv.2009.07.011.

20. Hayajneh WA, Balbeesi A, Faouri S. Hepatitis a virus age-specific seroprevalence and risk factors among Jordanian children. J Med Virol. 2015; 87(4):569-74. https://doi.org/10.1002/jmv.24137.

21. Fix AD, Martin OS, Gallicchio L, Vial PA, Lagos R. Age-specific prevalence of antibodies to hepatitis a in Santiago, Chile: risk factors and shift in age of infection among children and young adults. Am J Trop Med Hyg. 2002; 66(5):628-32.

22. Peter E, Mark R. Leveraging Urbanization in South Asia: Managing Spatial Transformation for Prosperity and Livability. Washington, DC: World Bank. (C) World Bank; 2016. https://openknowledge.worldbank.org/handle/1 0986/22549 License: CC BY 3.0 IGO

23. Quaglio G, Ramadani N, Pattaro C, Cami A, Dentico P, Volpe A, et al. Prevalence and risk factors for viral hepatitis in the Kosovarian population: implications for health policy. J Med Virol. 2008;80(5):833-40. https://doi.org/ 10.1002/jmv.21141.

24. Yun H, Lee HJ, Yoon Y, Kim K, Kim S, Shin MH, et al. Seroepidemiology of hepatitis a infection in northeastern China, Korea, and Japan. Osong Public Health Res Perspect. 2012;3(1):31-5. https://doi.org/10.1016/j.phrp. 2012.01.005.

25. López-Gatell H, García-García L, Echániz-Avilés G, Cruz-Hervert P, OlamendiPortugal $M$, et al. Hepatitis a seroprevalence in adolescents and young adults in Mexico: a 2012 National Health and nutrition survey analysis. Vaccine. 2018;36(52):8094-9 https://doi.org/10.1016/j.vaccine.2018.10.037.

26. Kasturiratne A, Wickremasinghe AR, de Silva A. Morbidity pattern and household cost of hospitalisation for non-communicable diseases (NCDs): a cross-sectional study at tertiary care level. Ceylon Med J. 2005;50(3):109-13.

\section{Publisher's Note}

Springer Nature remains neutral with regard to jurisdictional claims in published maps and institutional affiliations.

Ready to submit your research? Choose BMC and benefit from:

- fast, convenient online submission

- thorough peer review by experienced researchers in your field

- rapid publication on acceptance

- support for research data, including large and complex data types

- gold Open Access which fosters wider collaboration and increased citations

- maximum visibility for your research: over $100 \mathrm{M}$ website views per year

At BMC, research is always in progress.

Learn more biomedcentral.com/submissions 